\title{
THE ARTERITIS OF RHEUMATOID ARTHRITIS
}

\author{
BY \\ BRUCE CRUICKSHANK \\ Department of Pathology, University of Edinburgh
}

(RECEIVED FOR PUBLICATION FEBRUARY 2, 1954)

The occurrence of vascular lesions in rheumatoid arthritis has been recognized for some time, but interest in them has been of a sporadic nature until recently. In the last few years American workers have published more detailed studies of arteritis in skeletal muscles, subcutaneous nodules, and synovial tissue (Sokoloff and others, 1951, 1953). Sokoloff and his colleagues regarded the lesion in the muscles as specific, but this has been questioned by other workers (Bauer, 1950; Rinehart, 1950). The arteritis has usually been subacute, but some observers have described appearances like those of polyarteritis nodosa (Graef and others, 1949; Case Records of the Massachusetts General Hospital, 1951), and occasionally an association has been noted between such lesions and treatment with ACTH or cortisone (Levin and others, 1953). At the meeting of the American Rheumatism Association in 1953, four workers or groups of workers referred to cases of generalized arteritis in rheumatoid arthritis, and this was frequently associated $\frac{0}{2}$ with hormone therapy (Robinson and others, 1953 and subsequent discussion). Arteritis was not ${ }_{i}^{\omega}$ described in the viscera in thirty fatal cases reported $-\vec{\omega}$ before the introduction of ACTH and cortisoneos (Baggenstoss and Rosenberg, 1943). Less interesto has been shown in the vascular lesions of rheumatoidarthritis in Great Britain, though reference has been ${ }_{\subseteq}$ made to arterial lesions in nodules (Collins, 1937), muscles and nerves (Cruickshank, 1952), and the heart and kidney (Ellman and Ball, 1948), and to theer occurrence of polyarteritis nodosa complicating hormone therapy (West and Newns, 1953).

No attempt has yet been made to correlate the arteritis found in muscles, nerves, and elsewhereo with the cardiac lesions found in fatal cases. It is the object of this paper to present such a study in 72 cases of the disease. It will be demonstrated that

TABLE I

TISSUES STUDIED, SHOWING DISEASE OF PATIENT AND SITE OF TISSUE

\begin{tabular}{|c|c|c|c|c|c|c|c|c|c|c|}
\hline \multirow{2}{*}{\multicolumn{4}{|c|}{ Disease }} & \multirow{3}{*}{ 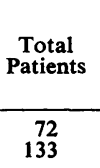 } & \multicolumn{6}{|c|}{ No. of Patients from whom Various Tissues were Studied } \\
\hline & & & & & \multirow{2}{*}{$\begin{array}{c}\text { Heart } \\
72\end{array}$} & \multirow{2}{*}{$\begin{array}{c}\begin{array}{c}\text { Synovial } \\
\text { Tissue }\end{array} \\
32 \\
36\end{array}$} & \multirow{2}{*}{$\begin{array}{c}\text { Muscle } \\
26 \\
68\end{array}$} & \multirow{2}{*}{$\begin{array}{c}\text { Nerve } \\
21\end{array}$} & \multirow{2}{*}{\begin{tabular}{|c|}
$\begin{array}{c}\text { Subcutan- } \\
\text { eous Nodule }\end{array}$ \\
5 \\
44
\end{tabular}} & \multirow{2}{*}{$\begin{array}{c}\text { Viscera } \\
\begin{array}{c}69 \\
1 \text { spleen }\end{array}\end{array}$} \\
\hline Rheumatoid Arthritis & $\left\{\begin{array}{l}\text { Autop } \\
\text { Biops }\end{array}\right.$ & & 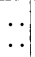 & & & & & & & \\
\hline Ankylosing Spondylitis & $\cdots$ & $\cdots$ & $\cdots$ & 17 & 5 & 8 & 10 & 2 & & 5 \\
\hline Osteo-Arthritis $\quad \ldots$ & $\ldots$ & $\ldots$ & - & 33 & & 27 & 9 & 1 & & 3 \\
\hline Gout & . & $\ldots$ & $\ldots$ & 4 & 4 & 2 & 2 & 1 & 2 & 2 \\
\hline Rheumatic Fever $\left\{\begin{array}{l}\text { Ac } \\
\text { He }\end{array}\right.$ & $\begin{array}{l}\text { ctive } \\
\text { ealed }\end{array}$ & $\begin{array}{l}\cdots \\
\cdots\end{array}$ & $\cdots$ & $\begin{array}{r}57 \\
196\end{array}$ & $\begin{array}{r}49 \\
199\end{array}$ & 9 & $\begin{array}{l}13 \\
15\end{array}$ & $\mathbf{7}$ & 6 & $\begin{array}{r}49 \\
170\end{array}$ \\
\hline Subacute Bacterial Endo & ocardit & & $\cdots$ & 27 & 23 & 2 & 4 & 1 & & 22 \\
\hline Systemic Lupus Erythen & matosu & & $\ldots$ & 14 & 14 & 8 & 9 & 9 & 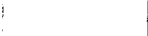 & 14 \\
\hline Polyarteritis Nodosa & $\ldots$ & $\cdots$ & $\ldots$ & 31 & 31 & 4 & 16 & 10 & 3 & 29 \\
\hline Dermatomyositis .. & $\ldots$ & $\ldots$ & $\cdots$ & 7 & 1 & & 7 & & 1 & 2 \\
\hline Scleroderma & . & $\cdots$ & $\ldots$ & 7 & 4 & 1 & 7 & & & 4 \\
\hline Henoch-Schönlein Purp & pura & $\ldots$ & $\ldots$ & 3 & \multicolumn{6}{|c|}{ Skin lesions from three cases. Muscle lesions from one case } \\
\hline Temporal Arteritis & $\cdots$ & $\ldots$ & $\ldots$ & 6 & \multicolumn{6}{|c|}{ Temporal and/or occipital arteries from six cases } \\
\hline Granuloma Annulare & $\cdots$ & $\cdots$ & $\cdots$ & 11 & \multicolumn{6}{|c|}{ Cutaneous lesions from nine cases. } \\
\hline \multicolumn{11}{|c|}{136} \\
\hline
\end{tabular}


arteritis occurs both in the heart and in other situations in an appreciable proportion of cases, and that some of the cardiac lesions hitherto interpreted as evidence of rheumatic heart disease can be regarded as part of the pathology of rheumatoid arthritis.

\section{Material}

Tissues were obtained at autopsy in 72 cases of rheumatoid arthritis (Table I). Blocks were taken from the heart, synovial tissue, muscle, nerve, and nodule in only three cases, from four of these tissues in fourteen cases, from three tissues in five cases, from two tissues in seventeen cases, and from the heart alone in 33 cases. In 43 instances, multiple blocks were taken from the heart, using the technique of Gross and others (1930), and multiple blocks were usually taken from synovial tissue, muscle, and nerve when these were examined. As a rule, single sections stained with haematoxylin and eosin were examined, but extra stains or serial sections were occasionally used. This autopsy material was compared with specimens obtained at biopsy from 133 cases of rheumatoid arthritis, and with both autopsy and biopsy material from 413 other cases of rheumatic and vascular disease, as indicated in Table I.

\section{Results}

Arteritis, or evidence of previous arteritis, was found in eighteen of the 72 cases of rheumatoid arthritis coming to autopsy. These cases have been divided into two groups, according to whether evidence of rheumatic heart disease was present or not. The lesions accepted as indicating rheumatic heart disease were myocardial Aschoff bodies, active or healed valvulitis, and active or healed left auricular endocarditis.

Group I. Cases with Evidence of Rheumatic Heart Disease.-Seven cases fell into this group. The anatomical distribution of the lesions and certain other information about the patients is presented in Table II. The patients were mostly elderly (average age 70) with inactive arthritis of considerable duration. A previous history of rheumatic fever was obtained in only two cases. The only patient under 50 years of age in the group (Case 10) had inactive rheumatoid arthritis of short duration but was found to have active rheumatic carditis at autopsy. The vascular lesions in the heart were

TABLE II

CASES OF RHEUMATOID ARTHRITIS WITH RHEUMATIC HEART DISEASE (Group I)

\begin{tabular}{|c|c|c|c|c|c|c|c|c|c|c|c|c|}
\hline \multirow{3}{*}{$\begin{array}{l}\text { Case } \\
\text { No. }\end{array}$} & \multirow{3}{*}{ Sex } & \multirow{3}{*}{$\begin{array}{l}\text { Age } \\
\text { (yrs) }\end{array}$} & \multirow{3}{*}{$\begin{array}{c}\text { Duration } \\
\text { of Rheu- } \\
\text { matoid } \\
\text { Arthritis } \\
\text { (yrs) }\end{array}$} & \multirow{3}{*}{$\begin{array}{c}\text { Clinical } \\
\text { Activity } \\
\text { of } \\
\text { Rheu- } \\
\text { matoid } \\
\text { Arth- } \\
\text { ritis at } \\
\text { Death }\end{array}$} & \multicolumn{7}{|c|}{ Pathological Findings } & \multirow{3}{*}{$\begin{array}{c}\text { History } \\
\text { of } \\
\text { Rheumatic } \\
\text { Fever }\end{array}$} \\
\hline & & & & & \multicolumn{2}{|c|}{ Heart } & \multicolumn{5}{|c|}{ Other Sites of Arteritis } & \\
\hline & & & & & $\begin{array}{l}\text { Cardiac } \\
\text { Arteritis }\end{array}$ & $\begin{array}{l}\text { Other } \\
\text { Lesions }\end{array}$ & $\begin{array}{c}\text { Syno- } \\
\text { vial } \\
\text { Tissue }\end{array}$ & Muscle & Nerve & $\begin{array}{l}\text { Subcut- } \\
\text { aneous } \\
\text { Nodule }\end{array}$ & Viscera & \\
\hline 4 & $\mathbf{F}$ & 82 & 5 & - & $\begin{array}{l}\text { Posterior papil- } \\
\text { lary muscle }\end{array}$ & $\begin{array}{l}\text { Adherent peri- } \\
\text { cardium } \\
\text { Mitral stenosis } \\
\text { Aortic fibrosis }\end{array}$ & & 0 & & + & 0 & 0 \\
\hline 7 & $\mathbf{F}$ & 82 & 6 & - & Left ventricle & $\begin{array}{l}\text { Pericardial } \\
\text { fibrosis } \\
\text { Mitral stenosis }\end{array}$ & $\mathbf{0}$ & 0 & $\mathbf{0}$ & & 0 & Childhood \\
\hline 10 & $\mathbf{M}$ & 48 & $1 \frac{1}{2}$ & - & $\begin{array}{l}\text { Posterior papil- } \\
\text { lary muscle }\end{array}$ & $\begin{array}{l}\text { Adherent peri- } \\
\text { cardium } \\
\text { Active myocar- } \\
\text { ditis } \\
\text { Active valvulitis }\end{array}$ & 0 & 0 & 0 & & 0 & $\begin{array}{c}\text { Active at } \\
\text { death }\end{array}$ \\
\hline 11 & $\mathbf{F}$ & 82 & $?$ & - & 0 & $\begin{array}{l}\text { Mitral stenosis } \\
\text { Aortic fibrosis }\end{array}$ & 0 & $\mathbf{0}$ & + & & 0 & 0 \\
\hline 15 & $\mathbf{F}$ & 72 & Many & - & Left ventricle & $\begin{array}{l}\text { Pericardial } \\
\text { fibrosis } \\
\text { Mitral fibrosis } \\
\text { Aortic fibrosis }\end{array}$ & 0 & & & 0 & 0 & 0 \\
\hline 16 & $\mathbf{F}$ & $?$ & Many & - & Left ventricle & $\begin{array}{l}\text { Pericardial } \\
\text { fibrosis } \\
\text { Mitral fibrosis } \\
\text { Aortic fibrosis }\end{array}$ & & & & & $\mathbf{0}$ & 0 \\
\hline 18 & $\mathbf{M}$ & 56 & 10 & + & Left ventricle & $\begin{array}{l}\text { Pericardial } \\
\text { fibrosis } \\
\text { Mitral stenosis } \\
\text { Aortic fibrosis }\end{array}$ & $\mathbf{0}$ & 0 & & & 0 & $\begin{array}{l}\text { 32-36 yrs } \\
\text { before } \\
\text { death }\end{array}$ \\
\hline \multicolumn{3}{|c|}{ Number with Arteritis } & .. & $\cdots$ & 6 & & 0 & 0 & 1 & 1 & 0 & \\
\hline
\end{tabular}


confined to the left ventricular myocardium. In six of the cases the lesions were of old standing and inactive (Fig. 1), and in the seventh (Case 10) subacute arteritis accompanied the active rheumatic carditis (Figs 2 and 3). Arteritis was seen outside the heart in Case 11 only-in one of three blocks of femoral nerve. The appearances were of a healing subacute arteritis associated with thrombosis (Fig. 4).

Group II. Cases without Evidence of Rheumatic Heart Disease.-Group II contains eleven cases of younger average age (58) than Group I, and the rheumatoid process was active at death in half of them although of longer duration than in Group I (Table III). Cardiac lesions other than arteritis were present in six cases, but cannot be regarded as indicative of rheumatic heart disease. The pericarditis in Case 17 and the myocarditis in Cases 2, 8,9 , and 17 were all non-specific. The endocardial lesions in the mitral ring and valve of Case 1 were those of "rheumatoid" endocarditis (Baggenstoss and Rosenberg, 1944). Calcareous aortic stenosis, which was present in Case 17, is included in this group because of the doubt about its rheumatic basis (Clawson and others, 1938; Sohval and Gross, $\bar{\Xi}$ 1936; Karsner and Koletsky, 1947; Hultgren, 1948). 으.

The vascular lesions in the heart were usually seen in small arteries. They were usually found in only $\overrightarrow{\vec{C}}$ one of the blocks studied. The most florid changes were seen in Case 8 in the form of infiltration of all $\frac{\mathrm{C}}{0}$ coats of the vessel with round cells (Fig. 5, overleaf). This was most marked in the adventitia where $\overrightarrow{\mathbb{D}}$ lymphocytes predominated, whereas in the other coats the infiltrating cells were less numerous and $\mathrm{c}$ were mostly histiocytes. The internal elastic lamina $\overrightarrow{0}$ showed several defects (Fig. 6, overleaf), but no $\overrightarrow{\vec{H}}$ wholesale necrosis of tissue such as occurs in $\tilde{\sigma}^{-}$ polyarteritis nodosa. The media was oedematous and both it and the intima were thickened by $\bar{a}$ fibrosis. This had caused narrowing of the lumen $\vec{\omega}$ but there was no thrombosis. Another vessel in i this heart showed a later stage in the process with $\vec{\omega}$ much fibrosis of the media, complete destruction? of elastic tissue, and an organizing thrombus in the lumen. Healing arteritis was seen in several $\vec{c}$ epicardial vessels in Case 17, in the form of fibrosis with distortion of the media where muscle but not ${ }^{\Phi}$ elastic tissue had been lost (Fig. 7, overleaf). The $\overrightarrow{0}$ remains of round-cell infiltration was seen in and $\oplus$

TABLE III

CASES OF RHEUMATOID ARTHRITIS WITHOUT RHEUMATIC HEART DISEASE (Group II)

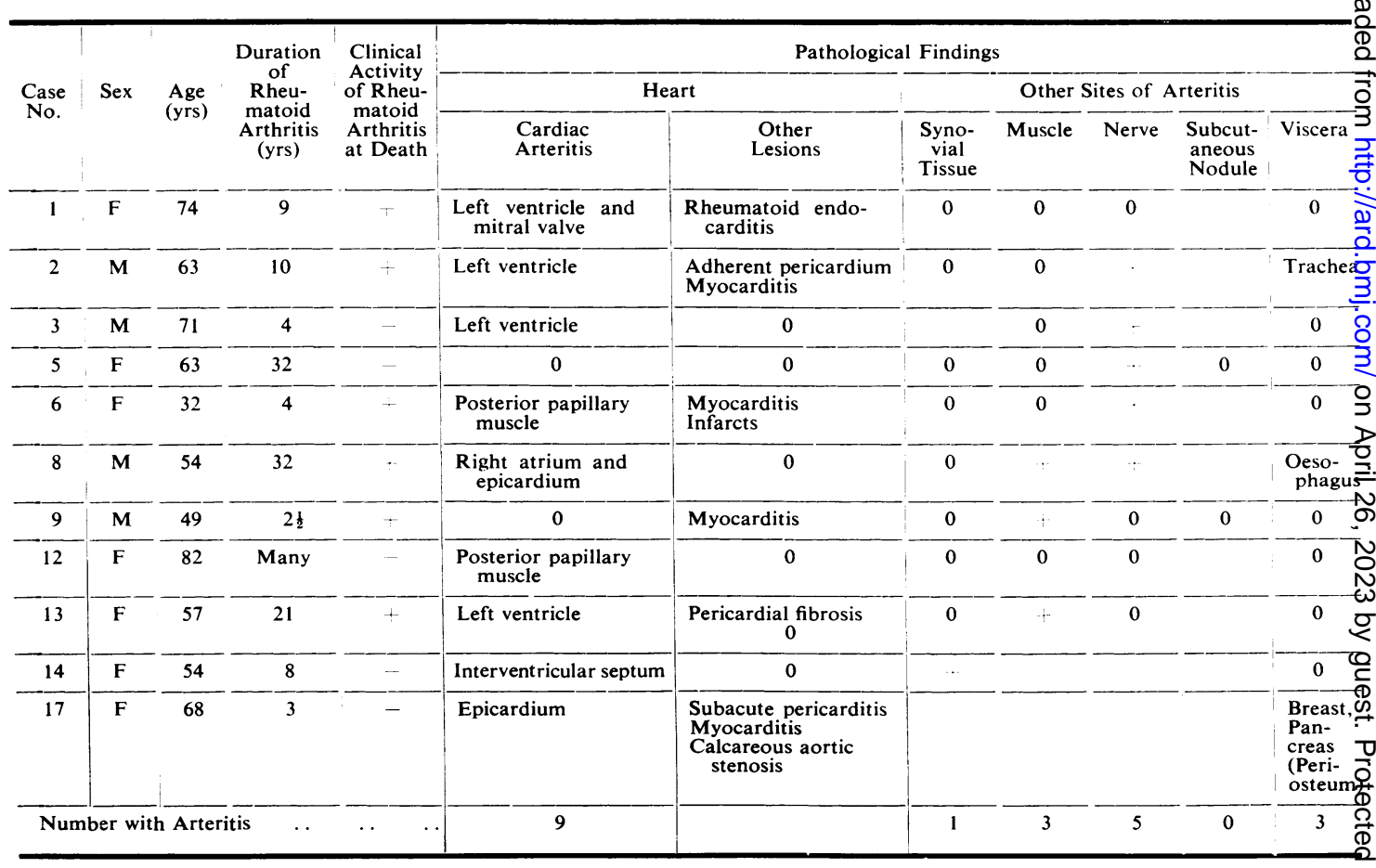




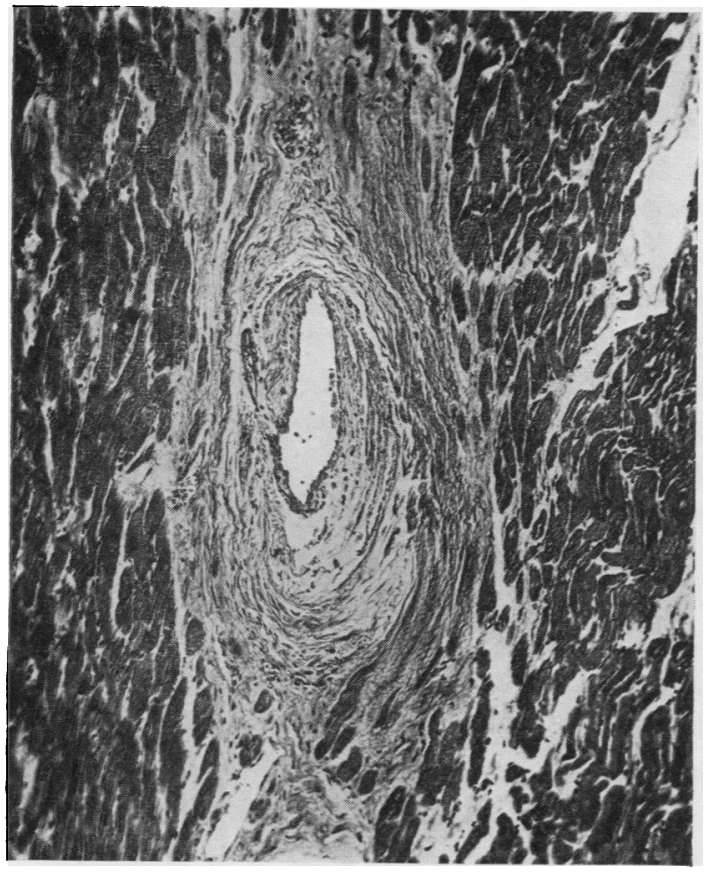

Fig. 1.-Case 18, left ventricle. Healed arteritis and periarterial fibrosis, minimal atheroma present in main coronary arteries. Haematoxylin and eosin. $\times 100$.

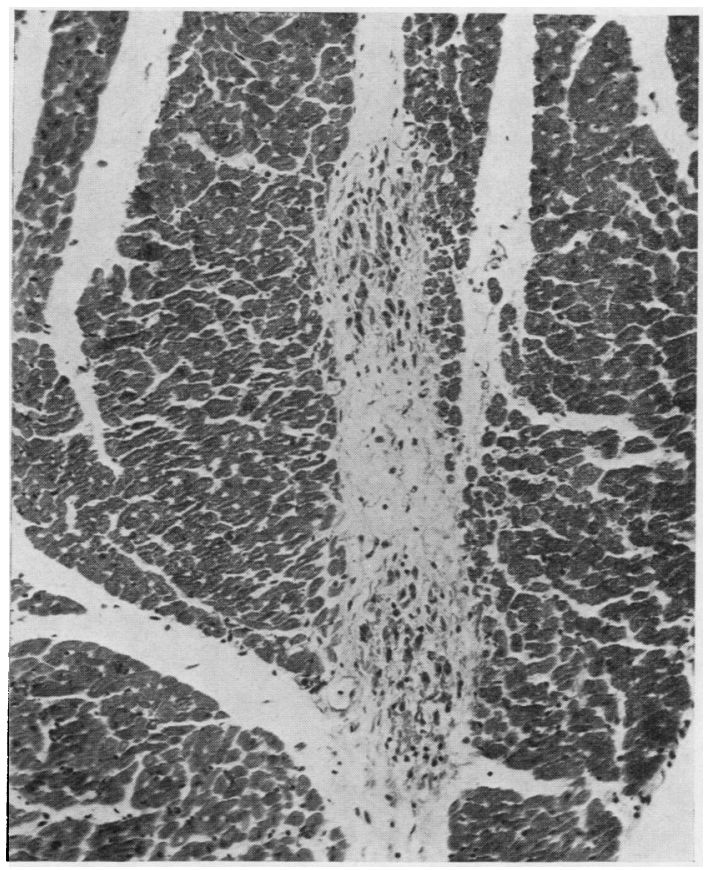

Fig. 2.-Case 10, interventricular septum. Two fully-developed Aschoff bodies lie close together in a small septum. Haematoxylin and eosin. $\times 100$.

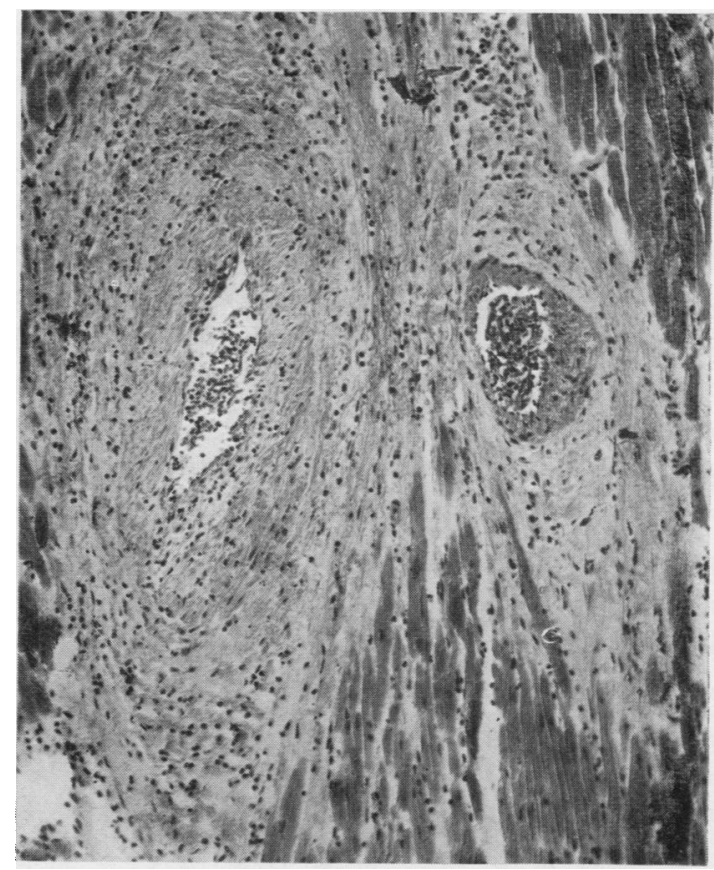

Fig. 3.-Case 10, posterior papillary muscle. Subacute arteritis with much fibrosis of vessel walls and adjacent tissue. Haematoxylin and eosin. $\times 100$.

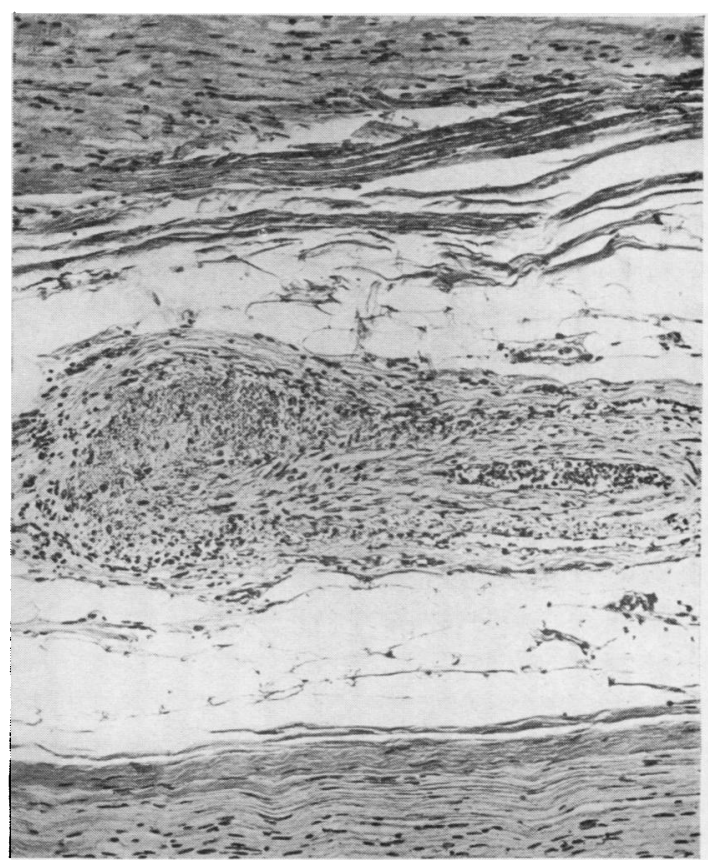

Fig. 4.-Case 11, femoral nerve. Subacute arteritis with thrombosis. Haematoxylin and eosin. $\times 100$. 


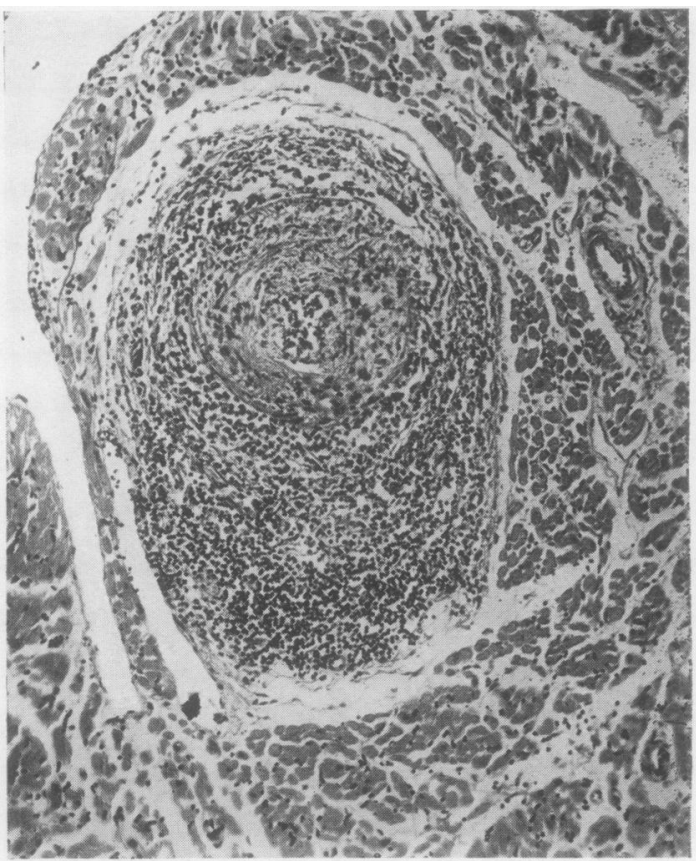

Fig. 5.-Case 8, right auricle. Intense subacute arteritis affecting all coats. Haematoxylin and eosin. $\times 100$.

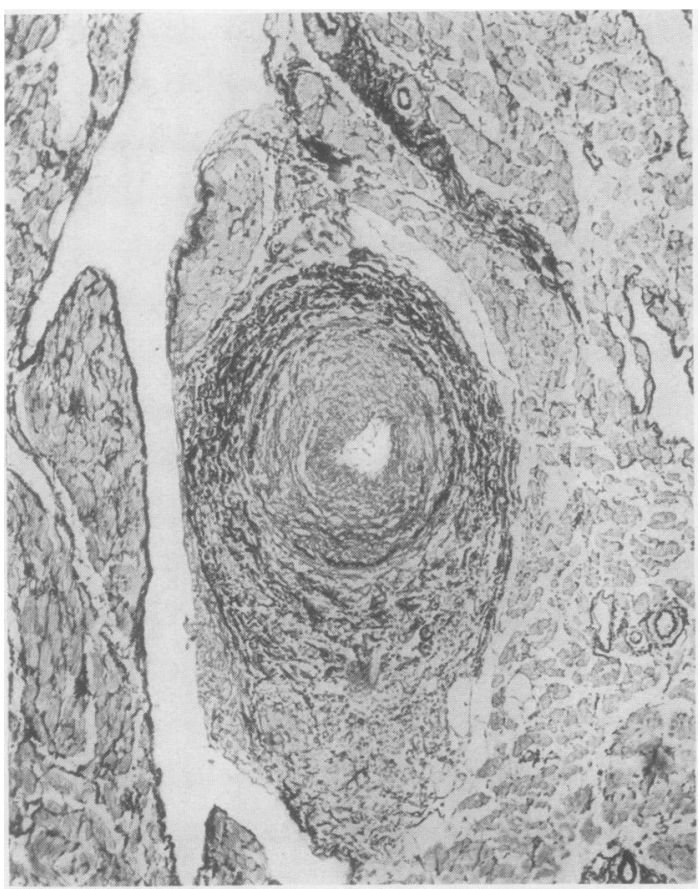

Fig. 6.-Case 8, same vessel as in Fig. 5, showing patchy destruction of elastic tissue. Weigert's elastic tissue stain. $\times 100$.

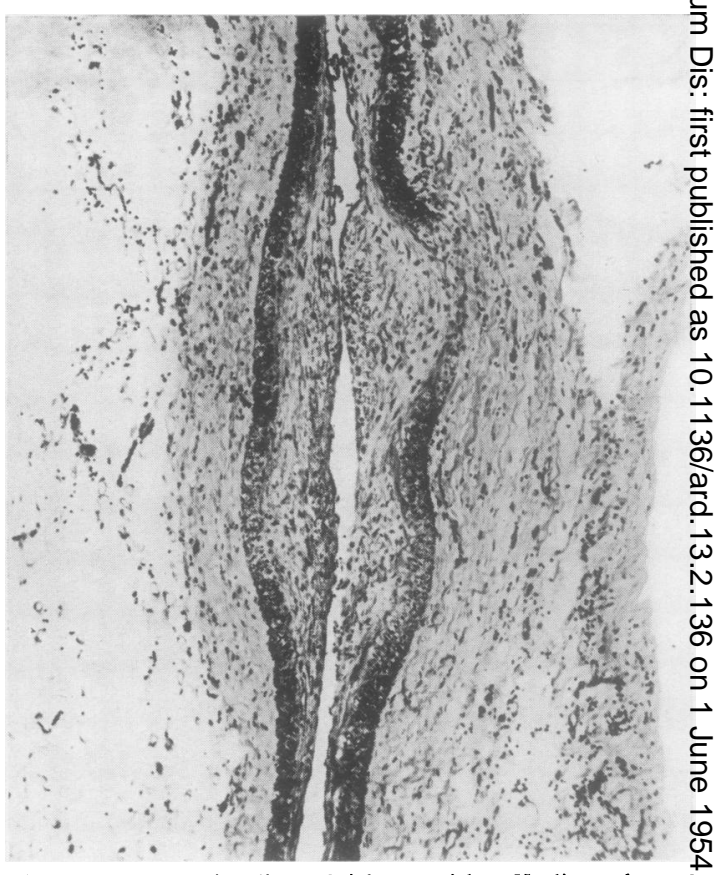

Fig 7-Case 17, epicardium of right ventricle. Healing subacute arteritis with loss of medial tissue. Haematoxylin and eosin.

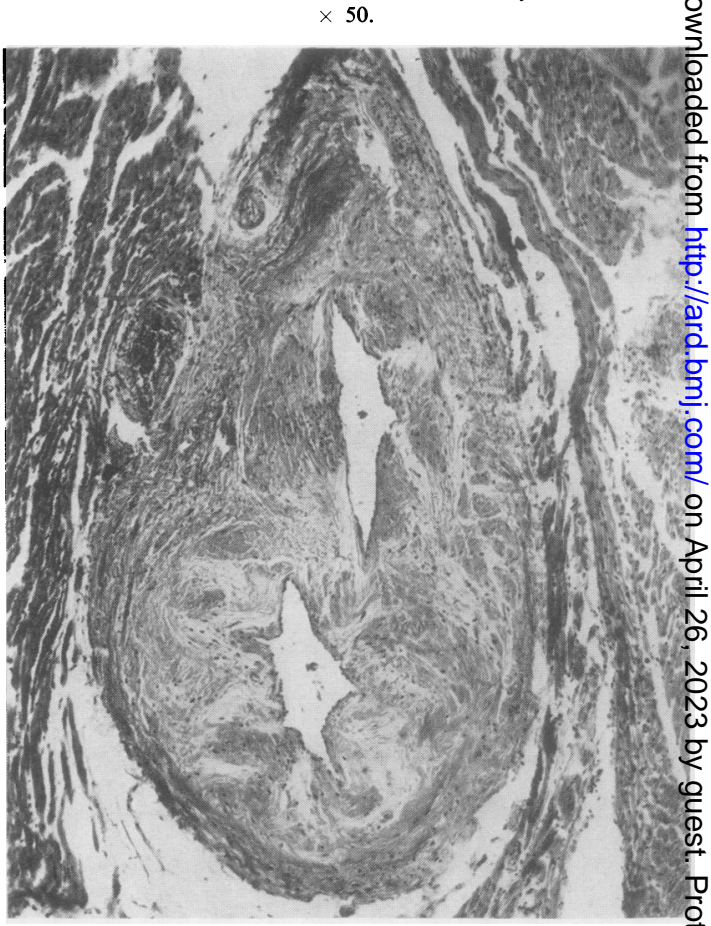

Fig. 8.-Case 6, posterior papillary muscle. Healed arteritis and periarterial fibrosis, no atheroma in main coronary arteries Haematoxylin and eosin. $\times \mathbf{4 0}$. 
around the affected vessels and generalized infiltration with such cells occurred in the outer part of the epicardium. In five other cases $(1,6,12,13$, and 14) only healed lesions were detected-intimal fibrosis with variable loss of elastic tissue and disruption of the media with fibrosis (Fig. 8). These lesions were accompanied by many small organizing infarcts in Case 6. A peculiar focal accumulation of lymphocytes and histiocytes was seen in the media and adventitia in an artery in the right ventricle in Case 3. This was accompanied by some distortion of the vessel wall but no necrosis was seen (Fig. 9). Involvement of arterioles was seen only in Case 2 where arteriolonecrosis accompanied a diffuse non-specific subacute myocarditis of the left ventricle.

The vascular lesions in the other tissues were again present in only a few of the blocks studied. Thus in synovial tissue at least three blocks were taken, yet only a single lesion was found; an average of seven blocks of muscle and eight of nerve were taken, and lesions were found usually in only one block of muscle and two of nerve. Most of the changes seen covered the same range as in the heart. In some cases they were of the same degree and stage as the

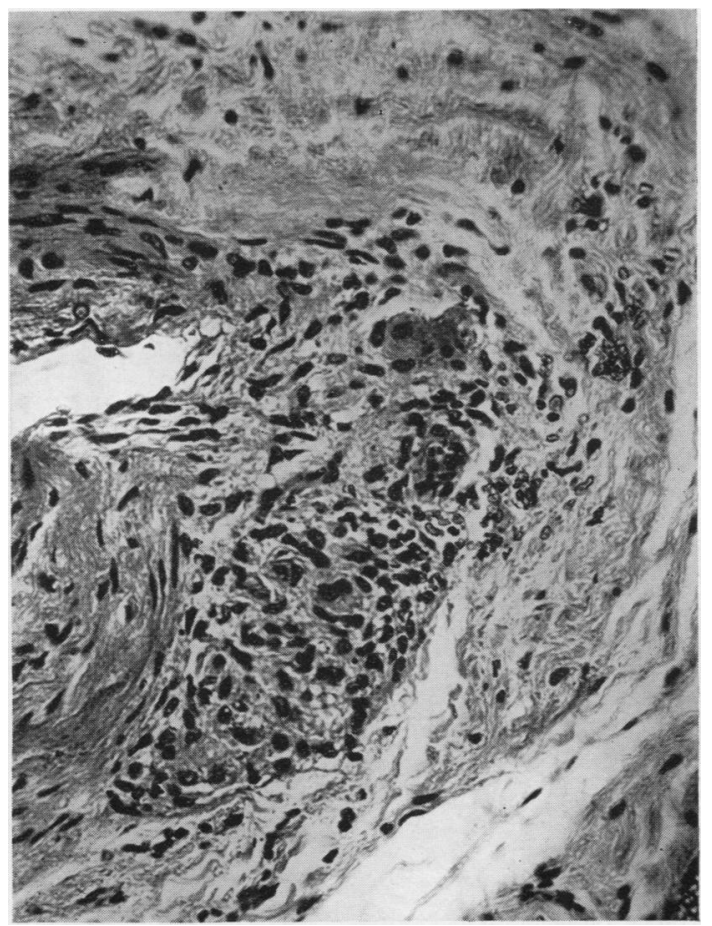

Fig. 9.- Case 3, right ventricle. Focal accumulation of lymphocytes and histiocytes in moderate-sized artery, minimal atheroma present in main vessels. Haematoxylin and eosin. $\times 100$. lesions in the heart (Cases 6 and 8). In others there were decided differences between cardiac and extracardiac lesions. Thus in Case 2 the tracheal and nerve lesions affected small arteries and were at a more advanced stage than in the heart (Fig. 10; and see Cruickshank, 1952, Fig. 19), and in Case 13 active arteritis was seen in nerve, whereas the cardiac lesion was healed. In Case 8, the arteritis in muscle and nerve was subacute as in the heart (see Cruickshank, 1952, Figs 17 and 18), but in the oesophagus a smaller vessel showed more recent necrosis accompanied by round-cell infiltration (Fig. 11, overleaf). Acute necrotizing arteritis affecting a larger vessel was seen in a nodule in the breast in Case 17 (Fig. 12, overleaf). The neighbouring breast tissue showed cystic hyperplasia. The lesions in the pancreas and sternal periosteum of this case were similar to those already described in the heart. Vascular lesions were seen twice in nodules, once in a small artery in the peripheral zone of an established nodule where an obliterative lesion had developed (Case 4, Fig. 13, overleaf), and once in relation to arterioles in a biopsy from a case of juvenile rheumatoid arthritis (Fig. 14, overleaf).

No vascular lesions were seen in other situations

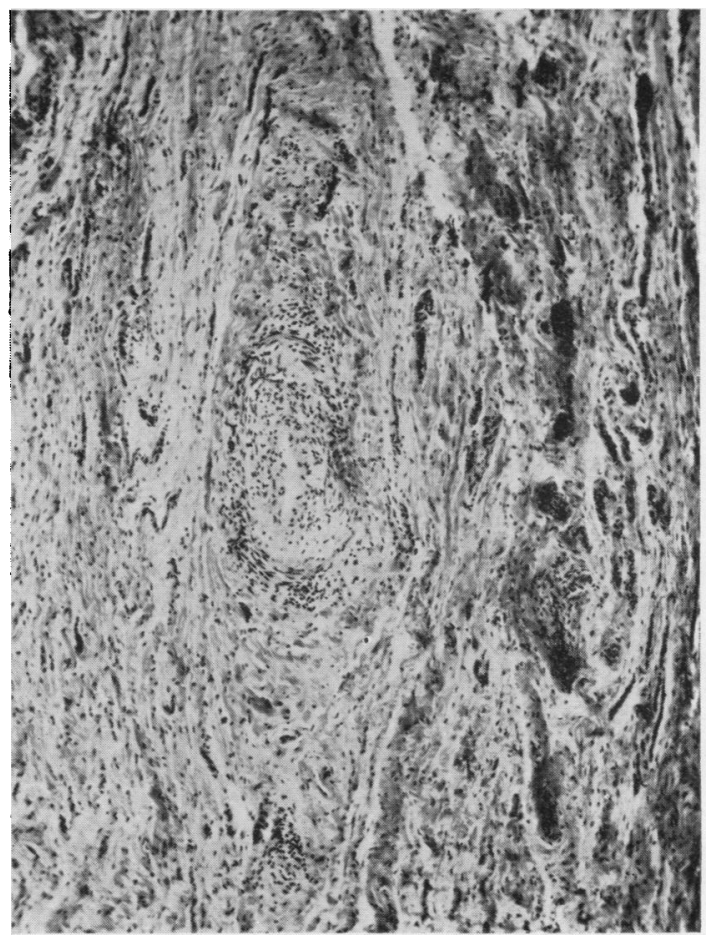

Fig. 10.-Case 2, fibrous nodule between trachea and oesophagus. Healing subacute arteritis. Haematoxylin and eosin. $\times 50$ 


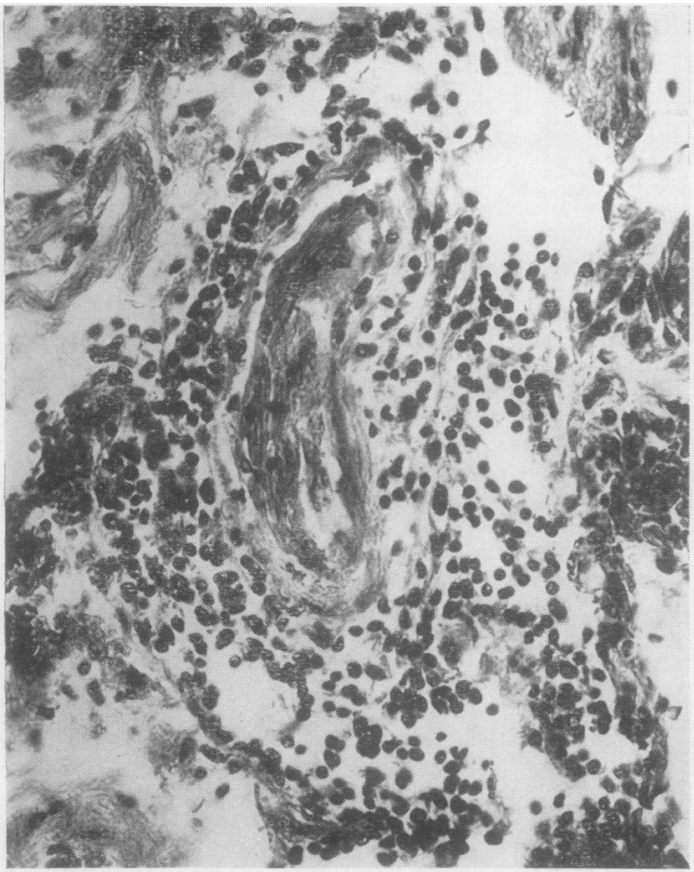

Fig. 11.-Case 8, oesophagus. Recent necrosis of large arteriole with round cell response. Haematoxylin and eosin. $\times 250$.

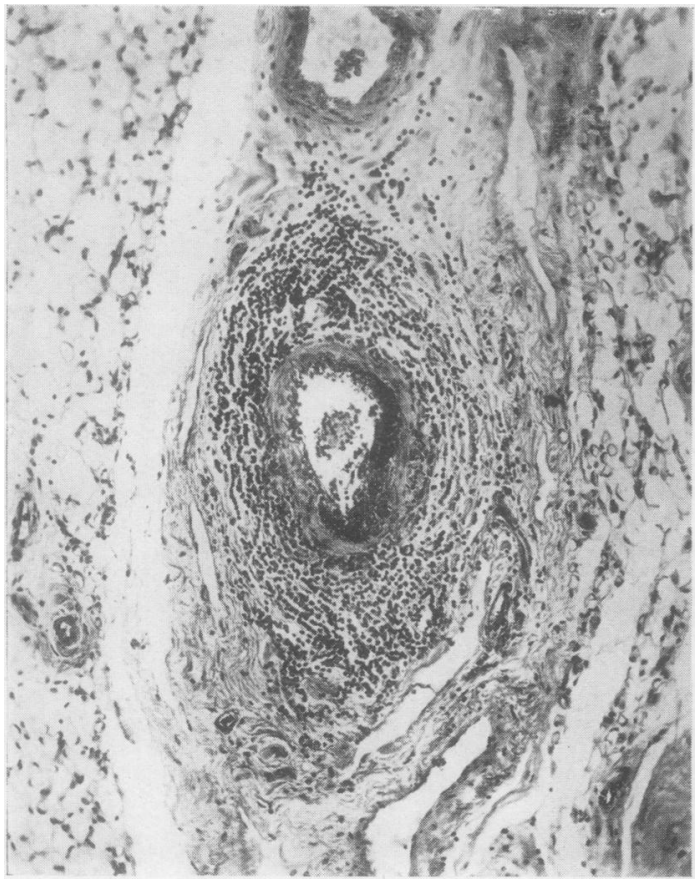

Fig. 12.-Case 17, right breast. Segmental necrosis and subacute arteritis. Haematoxylin and eosin. $\times 100$

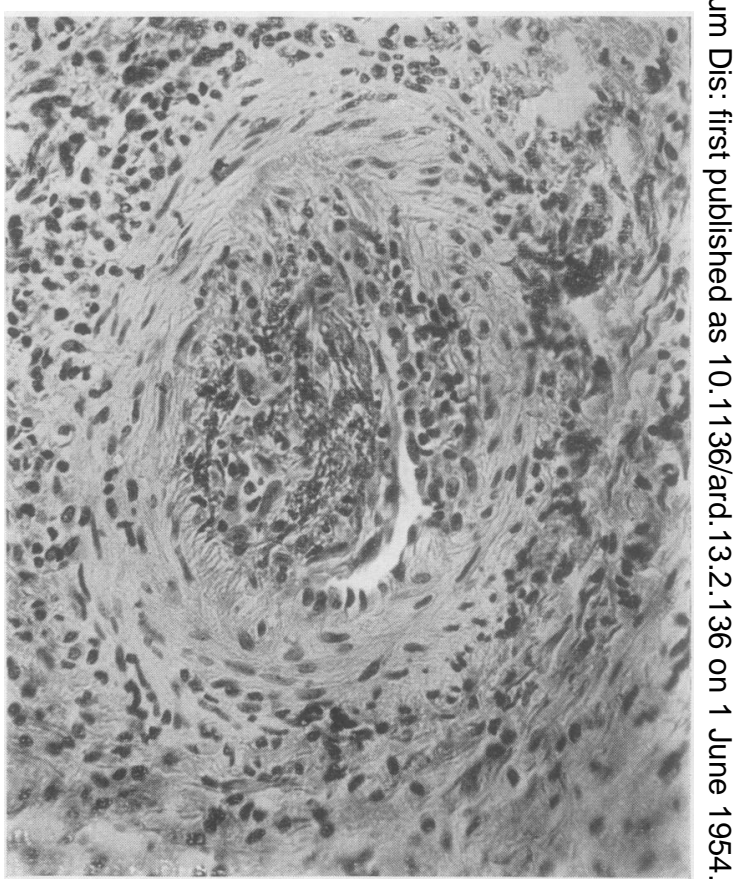

Fig. 13.-Case 4, subcutaneous nodule. Small artery in outer zone with intimal and adventitial infiltration. Haematoxylin and eosin. $\times 200$.

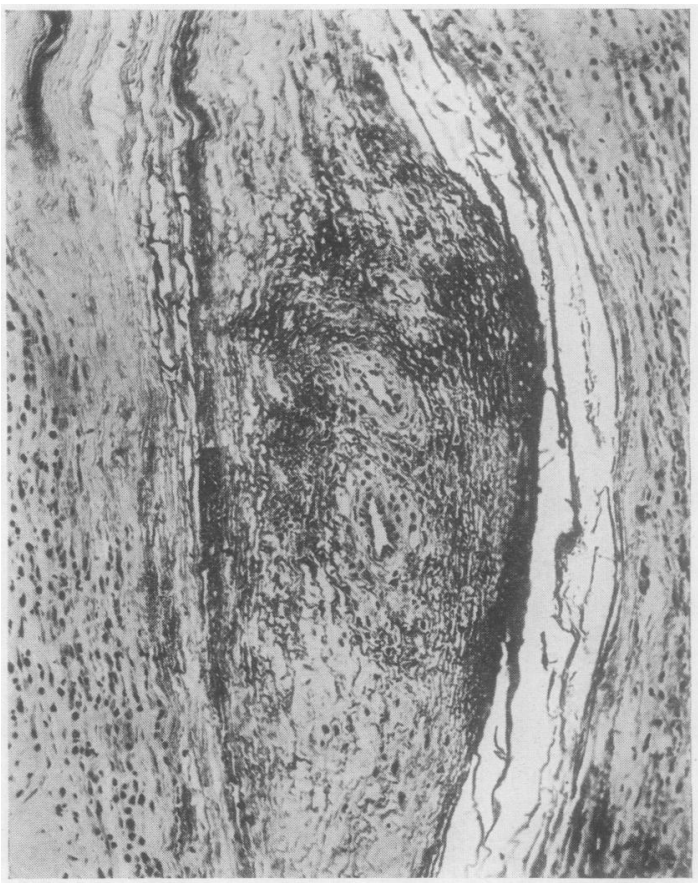

Fig. 14.-Subcutaneous nodule obtained at biopsy in a case of juvenile rheumatoid arthritis. Haematoxylin and eosin. $\times 100$.

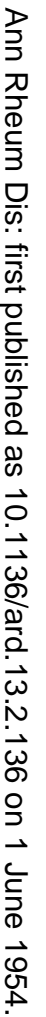


although sections were examined from lung, liver, kidney, and spleen in all cases, and from other tissues such as gut, pancreas, lymph nodes, pituitary, adrenal, brain, and bone marrow in up to one-third of the total series.

\section{Discussion}

Arteritis, or evidence of previous arteritis, was found in eighteen of the 72 cases of rheumatoid arthritis studied at autopsy. These eighteen cases have been subdivided into two groups on the basis of the presence or absence of cardiac lesions indicative of rheumatic carditis. Practically all the arterial changes seen in Group I can be identified with past or present rheumatic carditis, and with one exception they were confined to the heart. In Group II there was no evidence of rheumatic heart disease, nor were any of the other conditions present which are associated with more or less generalized arteritis, e.g. polyarteritis nodosa, systemic lupus erythematosus, etc. The other pathological processes found at autopsy in this group are listed in Table IV. It is thus evident that the only features common to this group of eleven cases are rheumatoid arthritis and arteritis.

TABLE IV

ASSOCIATED DISEASES IN ARTERITIS IN RHEUMATOID ARTHRITIS CASES WITHOUT RHEUMATIC HEART DISEASE

\begin{tabular}{ll}
\hline Case No. & \multicolumn{1}{c}{ Disease } \\
\hline 1 & nil \\
\hline 2 & pyelitis, early amyloidosis \\
\hline 3 & post-hepatitic cirrhosis, carcinoids \\
\hline 5 & transverse "myelitis", hypertension \\
\hline 6 & nil \\
\hline 9 & acute liver necrosis, recent mild gold dermatitis \\
\hline 12 & bilateral thalamic infarcts \\
\hline 13 & fractured femur, cystitis \\
\hline 14 & pulmonary tuberculosis \\
\hline 17 & nil \\
\hline
\end{tabular}

The changes seen in the vessels were very similar to those described in the muscles by Sokoloff and others (1951). The vessels involved were usually small arteries of the muscular type, though arterioles can be affected (Cases 2 and 5). The anatomical distribution favoured those tissues in which other lesions are known to occur in rheumatoid arthritisthe heart (nine cases), peripheral nerves (five cases), skeletal muscles (three cases), and synovial tissue (one case). Arteritis was only occasionally seen in the viscera, and did not occur in the organs usually affected in other forms of arteritis. Damage to the vessel was usually less severe than that encountered in polyarteritis nodosa, so that aneurysm formation was not seen and thrombosis was seen only twice (Cases 8 and 11). Nevertheless, necrosis was a feature in a few instances (Cases 2, 8, and 17), and destruction of elastic tissue and haemosiderin pigment were also encountered. The cellular reaction was of subacute type and affected the adventitia to a greater exteni than the other two coats. That the vascular damage may occur over a considerable period of time is indicated by the presence of lesions at several stages of development in some of the patients (Cases 5, 8, 13, and 17).

None of these arterial lesions is specific, but the changes encountered in these cases of rheumatoid arthritis differ in several respects from the lesions of other types of arteritis. Viscera other than the heart have been examined in a sufficient number of cases of rheumatoid arthritis to indicate that they are not usually involved. The anatomical distribution, apart from the heart, differs from that of rheumatic fever, polyarteritis nodosa, systemic lupus erythematosus, dermatomyositis, scleroderma, Henoch-Schönlein purpura, or temporal arteritis. The last two conditions can also be distinguished by the morphology of the lesions. Although individual lesions encountered in rheumatoid arthritis and in the other arterial diseases have certain resemblances, the rheumatoid cases lack the other changes characteristic of these diseases, and the general picture of the vascular changes in rheumatoid arthritis differs from that in the other diseases.

The high incidence of cardiac arteritis in rheumatoid arthritis helps to explain some of the difficulties in the interpretation of the cardiac pathology of the disease. The occurrence of rheumatic heart disease in various studies has been reviewed recently by Sokoloff (1953), who records an incidence varying from 18 to 66 per cent. These figures cannot be regarded as completely accurate, for most of the studies have been reported from America and include cases of ankylosing spondylitis along with those of rheumatoid arthritis. However, when allowance is made for such cases the figures still show a similar wide divergence. This may be partly due to sampling errors, for several of the series have been small, but a more important factor is the variation in the criteria of diagnosis of the cardiac lesions. In the present series, only severe valvular damage (other than calcific aortic stenosis), active valvulitis, myocardial Aschoff bodies, and involvement of the left endocardium were accepted as diagnostic of rheumatic heart disease, and by 
these criteria, twelve cases (17 per cent.) were found to be affected. Very similar criteria were adopted by Bayles (1943) and Bennett (1943), who recorded incidences of 23 and 15 per cent. respectively in smaller series; in Sokoloff's series of 105 cases, 4 per cent. showed "frank rheumatic heart disease". Most writers who have recorded higher incidences do not define their criteria of rheumatic heart disease with precision, and some even include cases with only pericarditis (Young and Schwedel, 1944). If cases showing such features as pericarditis, arteritis, perivascular scars, and diffuse myocarditis in some combination were included in this series, the incidence would correspond to the higher figures previously reported, for by these standards forty cases (55 per cent.) could be regarded as positive. Coronary arteritis of the type seen in polyarteritis nodosa has been recorded by many observers in rheumatic carditis (Geipel, 1907; Wohlwill, 1923; MacCallum, 1925; Klinge and Vaubel, 1931; Wild, 1933; Collins, 1938; Rich and Gregory, 1943; McKeown, 1945; de Brux, 1948; Pagel, 1951), and vascular lesions of the same type have been described in systemic lupus erythematosus (Klemperer and others, 1941; Coburn and Moore, 1943; Griffith and Vural, 1951), in dermatomyositis (Fahr, 1921), and in scleroderma (Pollack, 1940). Many of the arterial lesions described in the heart in rheumatoid arthritis in this and previous studies have represented the end result of an active arteritis. It is probably justifiable to regard such old lesions as rheumatic if other diagnostic lesions are present (Group I), but such a conclusion does not seem warranted in the absence of other evidence of rheumatic heart disease (Group II). Likewise pericarditis as an isolated finding cannot be regarded as rheumatic (Smith and Willius, 1932), and diffuse or focal myocarditis without Aschoff bodies occurs in many conditions other than rheumatic carditis (Saphir, 1941, 1942).

Although this study indicates that arteritis is an important feature of the pathology of rheumatoid arthritis, it affords no clue to the pathogenesis of the arteritis. Analysis of the cases in Group II shows no striking correlation between the arteritis and any other feature of the disease. The average age of the patients and the sex incidence are the same as that for the whole series of 72 cases. Clinical activity at the time of death was seen in a much higher proportion of cases in Group II (6/11) than in the remaining cases where such information was available (14/58). But an attempt to connect arteritis in the heart, synovial tissue, muscles, and nerves with other lesions in these situations does not provide any outstanding correlation. Thus, the single example of an arterial lesion in synovial tissue occurred in the absence of active inflammation, whereas the examination of multiple blocks obtained either at biopsy or autopsy from over sixty cases, though frequently showing active synovitis revealed $\overline{0}$ no other instance of arteritis. In muscles and $\frac{0}{5}$ nerves, lymphorrhages and arteritis occurred in- के dependently of one another, and even when both $\mathbb{\nabla}$ were present the two lesions were usually unrelated. The arterial lesions in the oesophagus of Case 8 and in the pancreas and periosteum of Case 17 were not $\vec{O}$ associated with any other lesion. The tracheal $\overrightarrow{\vec{H}}$ lesion in Case 2 lay within a large patch of fibrosis. The acute arteritis in the breast in Case 17 lay next to a focus of cystic hyperplasia and may have been aetiologically connected with this rather than with $\vec{\omega}$ the arthritis; but acute necrotizing arteritis is a most unusual accompaniment of cystic hyperplasia. $\vec{\omega}$ Although no adequate explanation was found for 0 the thalamic infarcts in Case 9, there was no evidence of arteritis in the sections of brain studied. $c$ None of the nodules studied was sufficiently recent to provide data to support or refute the premise of Sokoloff and others (1953) that arteritis is a feature $\vec{G}$ of the early stage of the rheumatoid nodule, or the $\perp$ earlier suggestion of Bennett and others (1940) that the central necrosis might be due to infarction. Such lesions as were seen in nodules could readily be interpreted as secondary rather than primary.

No association could be established between the $\stackrel{\mathbb{D}}{\circ}$ arteritis and any therapeutic agent, except possibly in $\vec{F}$ Case 8. This patient had a mild gold dermatitis 3 weeks before his death. The skin lesion cleared up within a few days on BAL treatment, and no other evidence of a reaction to gold was seen clinically or in the tissues. Death was due to acute liver necrosis accompanying viral hepatitis. Gold was used in treatment in many other cases in the whole series, including Cases 1 and 2, but no lesions attributable to toxicity were seen. Toxic reactions $₹$ in eight cases lacking evidence of arteritis were $\frac{\text { 의 }}{2}$ directly related to the fatal outcome. The writer $D$ is not aware of any record of arteritis complicating treatment with gold in human patients, nor accom- N panying the production of renal damage with large doses in animals (Brown and others, 1926; Orestano, $\mathcal{O}$ 1933; Cortell and Richards, 1942). None of the $\mathrm{W}$ patients in this series had received ACTH or 疋 cortisone.

The incidence of arteritis in rheumatoid arthritis is probably considerably higher than that recorded here, for several cases were incompletely examined. Excluding the twelve cases with rheumatic heart disease, multiple blocks were taken from the heart in 33 cases, eight of which showed arteritis, whereas 
a single block was taken in 27 cases and only one showed arteritis. Synovial tissue, muscle, and nerve were examined in only one-third to one-half of the total number of cases. Examination of serial sections might also have increased the incidence.

\section{Summary}

(1) Vascular lesions were sought for in the heart and in other organs and tissues in 72 fatal cases of rheumatoid arthritis.

(2) Arteritis, past or present, was encountered in eighteen cases. In seven of these, lesions diagnostic of rheumatic heart disease were also found and the vascular involvement was mainly confined to the heart. In the remaining eleven cases, there were no pathological processes other than rheumatoid arthritis which might be associated with the arteritis, and the vascular lesions are considered to be the arteritis of rheumatoid arthritis.

(3) The arteritis of rheumatoid arthritis was encountered most frequently in the heart, muscles, and nerves, and occasionally in synovial tissue. No vascular lesions were encountered in those viscera which are commonly affected in other forms of generalized arteritis, though diseased vessels were sometimes found in certain unusual situations, e.g. periosteum, oesophagus, trachea.

(4) The arteritis usually seemed to be of subacute form, sometimes with necrosis, and it affected small arteries or arterioles. Thrombosis was unusual and aneurysm formation was not seen. Individual patients sometimes showed arterial lesions in different stages of development.

(5) The pathogenesis of the arteritis remains obscure. The vascular lesions were never regularly associated with any other lesion.

(6) The arteritis of rheumatoid arthritis, though not specifically identifiable, can be differentiated from that of polyarteritis nodosa, rheumatic fever, systemic lupus erythematosus, temporal arteritis, dermatomyositis, and scleroderma.

(7) The relation of arteritis of coronary vessels to the incidence of rheumatic heart disease in rheumatoid arthritis is discussed.

(8) The incidence of arteritis in rheumatoid arthritis is probably considerably higher than that recorded in this study.

I wish to thank Professor A. M. Drennan for his criticism and advice. Much of the material was collected during the tenure of a Research Grant from the Nuffield Foundation. The sections were prepared by various members of the technical staff of the Pathology Departments of the University and Royal Infirmary of Edinburgh, and the illustrations by the staff of the Photo- micrography Unit, University of Edinburgh, to all of whom I am grateful for their help.

\section{REFERENCES}

Baggenstoss, A. H., and Rosenberg, E. F. (1943). Arch. Path. (Chicago), 35, 503.

Bauer, $\frac{}{\text { W }}$ (1944). Ibid., 37, 54.

Bauer, W. (1950). In discussion on Bunim, J. J., Sokoloff, L., and Wilens, S. L. (1950). Annals of the Rheumatic Diseases, 9, 388.

Bayles, T. B. (1943). Amer. J. med. Sci., $205,42$.

Zeller, J. W., and Bauer, W. (1940). Arch. Path. (Chicago),

Brown, Ho, 70. Saleeby, E. R., and Schamberg, J. F. (1926). J. Pharmacol. exp. Ther,, 28, 141.

de Brux, J. (1948). Ann. Méd., 49, 278.

Clawson, B. J., Noble, J. F., and Lufkin, N. H. (1938). Amer. Heart J., 15, 58 .

Coburn, A. F., and Moore, D. H. (1943). Bull. Johns Hopk. Hosp.,

Collins, D. H. (1937). J. Path. Bact., 45, 97.

- (1938). Brit. J. Rheum., 1, 88.

Cortell, R., and Richards, R. K. (1942). J. Pharmacol. exp. Ther., 76, 17.

Cruickshank, B. (1952). J. Path. Bact., 64, 21.

Ellman, P., and Ball, R. E. (1948). Brit. med. J., 2, 816.

Fahr, T. (1921). Arch. Derm. Syph. (Wein), 130,1.

Geipel, P. (1907). Münch. med. Wschr., 54, 1057.

Graef, I., Hickey, D. V., and Altmann, V. (1949). Amer. Heart J., $37,635$.

Griffith, G. C., and Vural, I. L. (1951). Circulation, 3, 492. Gross, L., Antopol, W., and Sacks, B. (1930). Arch. Path. (Chicago),

Hultgren, H. N. (1948), Ibid., 45, 694.

Karsner, H. T., and Koletsky, S. (1947). "Calcific Disease of the Aortic Valve." Lippincott, Philadelphia.

Klemperer, P., Pollack, A. D., and Baehr, G. (1941). Arch. Path. (Chicago), 32, 569.

Klinge, F., and Vaubel, E. (1931). Virchows Arch. path. Anat. 281, 701 .

Levin, M. H., Rivo, J. B., Scott, W., Figueroa, W. E., Fred, L., and Barrett, T. F. (1953). Amer. J. Med., 14, 265

MacCallum, W. G. (1925). Amer, med. Ass., 84, 1545.

McKeown, F. (1945). Ulster med. J., 14, 97.

Massachusetts General Hospital, Case Records of the (1951). New Engl. J. Med., 245, 147.

Orestano, G. (1933). Arch. int. Pharmacodyn., 44, 259

Pagel, W. (1951). J. clin. Path., 4, 137.

Pollack, A. D. (1940). Arch. Path. (Chicago), 29, 859

Rich, A. R., and Gregory, J. E. (1943). Bull. Johns Hopk. Hosp., 73, 239.

Rinehart, J. F. (1950). In discussion on Bunim, J. J., Sokoloff, L., and Wilens, S. L. (1950). Annals of the Rheumatic Diseases, 9, 388.

Robinson, W. D., French, A. J., and Duff, I. F. (1953). Ibid., 12, 323.

Saphir, O. (1941). Arch. Path. (Chicago), 32, 1000.

- (1942). Ibid., 33, 88.

Smith, H. L., and Willius, F. A. (1932). Arch. int. Med., 50, 171, $192,410$.

Sohval, A. R., and Gross, L. (1936). Arch. Path. (Chicago), 22, 477. Sokoloff, L. (1953). Amer. Heart J., 45, 635. McCluskey, R. T., and Bunim, J. J. (1953). Arch. Path. (Chicago), $55,475$.

- Wilens, S. L., and Bunim, J. J. (1951). Amer. J. Path., 27, 157.

West, H. F., and Newns, G. R. (1953). Lancet, 2, 1123.

Wild, F. (1933). Virchows Arch. path. Anat., $290,116$.

Wohlwill, F. (1923). Ibid., 246, 377.

Young, D., and Schwedel, J. B. (1944). Amer. Heart J., 28, 1.

\section{L'artérite de l'arthrite rhumatismale \\ RÉSUMÉ}

(1) On a recherché les lésions vasculaires dans le coeur et dans les autres organes et tissus des 72 cas mortels d'arthrite rhumatismale.

(2) On a trouvé de l'artérite, récente ou ancienne, dans 18 cas. Dans sept d'entre eux on a aussi trouvé des lésions diagnostiques de la maladie rhumatismale du coeur dont l'atteinte vasculaire était presque exclusive. Dans les onze cas restants on n'a pas trouvé de processus morbide autre que l'arthrite rhumatismale; on peut donc considérer ces lésions vasculaires comme représentant l'artérite de l'arthrite rhumatismale. 
(3) On a trouvé l'artérite de l'arthrite rhumatismale le plus souvent dans le coeur, les muscles, les nerfs et quelquefois dans le tissu synovial. On n'a pas trouvé de lésions vasculaires dans les viscères habituellement atteints dans d'autres formes d'artérite généralisée, bien qu'on ait rencontré des vaisseaux malades aux endroits inaccoutumés, tels que périoste, oesophage ou trachée.

(4) L'artérite apparaissait généralement sous sa forme subaiguë, quelquefois avec nécrose, l'atteinte portant sur les petites artères et les artérioles. La thrombose était rare et il n'y avait pas de tendance à l'anévrisme. Certains cas présentaient des lésions artérielles aux différents étapes évolutifs.

(5) La pathogénie de l'artérite demeure obscure. On n'a jamais observé d'association constante entre la lésion vasculaire et une autre lésion définie.

(6) L'artérite de l'arthrite rhumatismale, bien que sans identité spécifique, peut être différenciée de celle de la polyartérite noueuse, du rhumatisme articulaire aigu, du lupus érythémateux disséminé, de la dermatomyosite et de la sclérodermie.

(7) On discute le rapport entre l'artérite des vaisseaux coronaires et la fréquence de la maladie rhumatismale du coeur au cours de l'arthrite rhumatismale.

(8) L'artérite de l'arthrite rhumatismale est probablement bien plus fréquente qu'il ne ressort de cette étude.

\section{Arteritis de la artritis reumatoide SUMARIO}

(1) Investigáronse lesiones vasculares del corazón y de los demás órganos y tejidos en 72 casos mortales de artritis reumatoide.
(2) Se encontró una arteritis, reciente o antigua, en 18 casos. En siete de éstos encontráronse también lesiones diagnósticas de la enfermedad reumática del corazón; la afección vascular de éste fué casi exclusiva. En los demás once casos la artritis reumatoide fué el $\overline{\hat{\omega}}$ único proceso mórbido encontrado y las lesiones vasculares se puden, pués, considerar como arteritis de la artritis reumatoide.

(3) La arteritis de la artritis reumatoide encontrose más frecuentemente en el corazón, en los músculos, los nervios y, a veces, en el tejido sinovial. No se encontraron lesiones vasculares en vísceras generalmente afectadas en otras formas de arteritis generalizada, aunque se hubiese encontrado vasos enfermos en sitios poco comunes, como en el perióstio, el esófago o en la tráquea.

(4) La arteritis presentábase generalmente en forma subaguda, a veces con necrosis y afectaba las pequeñas arterias y arteriolas. Trombosis fué rara y formación de aneurismo no se vió. En casos individuales se vió a veces lesiones arteriales en varias etapas evolutivas.

(5) La patogénesis de la arteritis queda oscura. No se ? observó asociación constante entre la lesión vascular y alguna otra lesión.

(6) La arteritis de la artritis reumatoide, aunque sin identidad específica, se puede diferenciar de la de la poliarteritis nodosa, del reumatismo poliarticular agudo, del lupus eritematoso diseminado, de la dermatomiositis y de la esclerodermia.

(7) Se discute la relación entre la arteritis de los vasos coronarios y la frecuencia de la enfermedad reumática del corazón en el curso de la artritis reumatoide.

(8) La arteritis de la artritis reumatoide es probablemente mucho más frecuente de lo registrado aquí. 